Mass Movement in

Two Selected Areas of

Western Washington County,

Pennsylvania

GEOLOGICAL SURVEY PROFESSIONAL PAPER 1170 -B

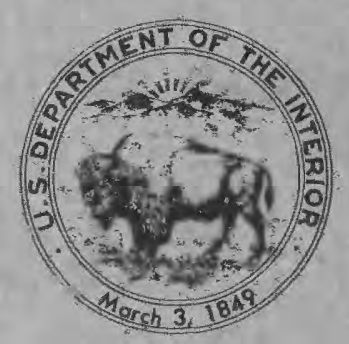


MASS MOVEMENT IN

TWO SELECTED AREAS OF WESTERN WASHINGTON COUNTY, PENNSYLVANIA 


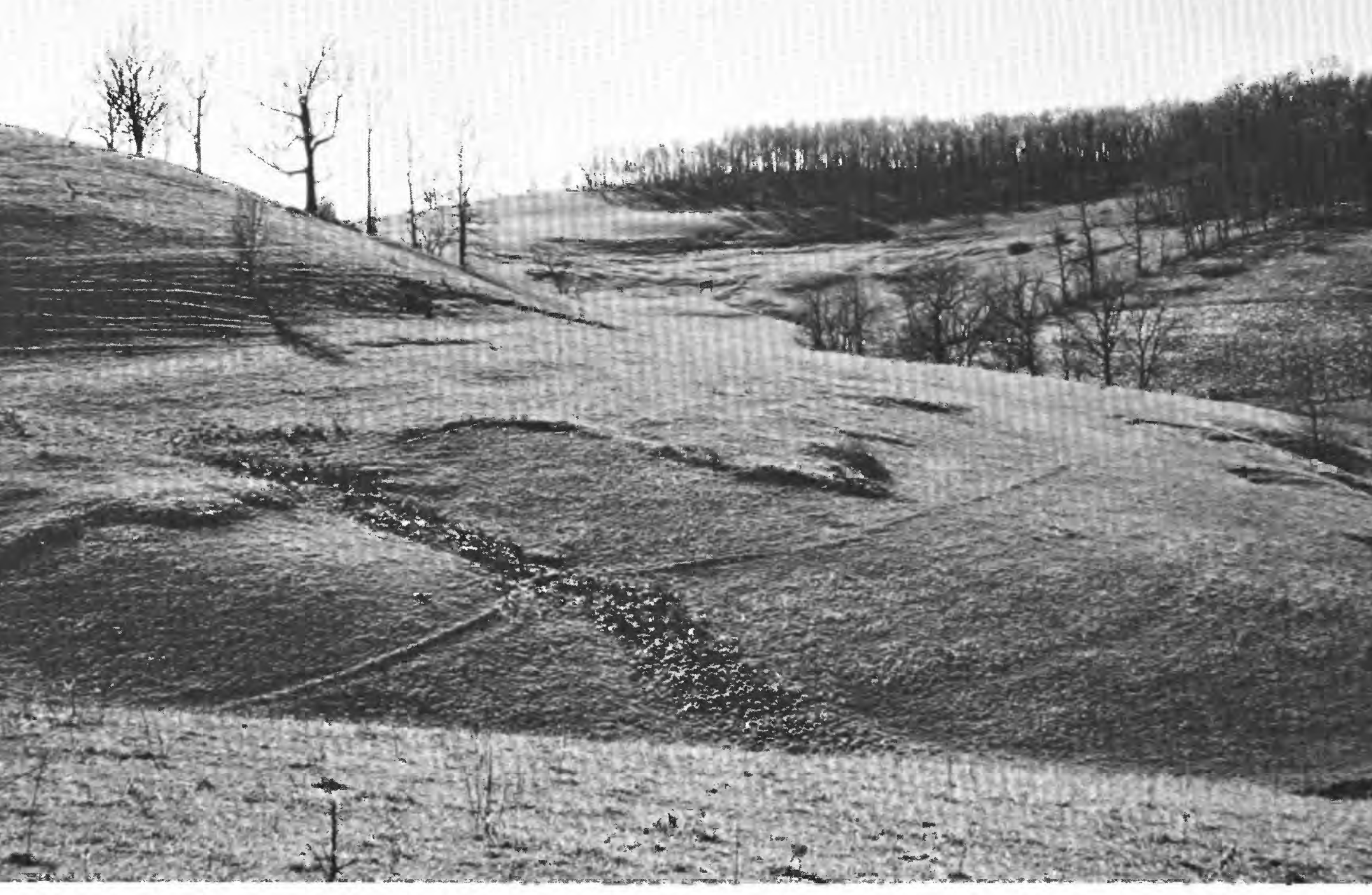

Recent earthflows along concave-convex east- to north-facing slopes west of Prosperity, Pa. 


\section{Mass Movement in \\ Two Selected Areas of \\ Western Washington County, \\ Pennsylvania}

By JOHN S. POMEROY

SHORTER CONTRIBUTIONS TO GENERAL GEOLOGY

GEOLOGICAL S URVEY PROFESSIONAL PAPER $1170-$ B Landsliding and its relation to geology and an analysis of various interpretive elements in a region of the Allegheny Plateau subject to landslides

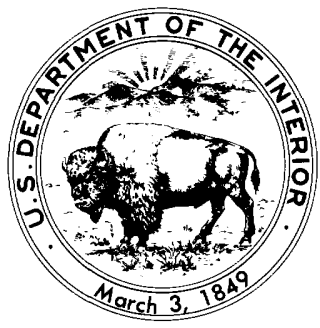




\section{UNITED STATES DEPARTMENT OF THE INTERIOR}

JAMES G. WATT, Secretary

GEOLOGICAL SURVEY

Dallas L. Peck, Director

\section{Library of Congress Cataloging in Publication Data}

Pomeroy, John S 1929-

Mass movement in two selected areas of western Washington County, Pennsylvania.

(Shorter contributions to general geology)

(Geological Survey professional paper ; 1170-B)

Bibliography: $p$.

Supt. of Docs. no.: I 19.16:1170-B

1. Mass-wasting-Pennsylvania-Washington Co. I. Title. II. Series: United States.

Geological Survey. Shorter contributions to general geology. III. Series: United States.

Geological Survey. Professional paper ; 1170-B.

QE599.U5P65 $551.3 \quad 80-607835$

AACR1

For sale by the Distribution Branch, U.S. Geological Survey, 604 South Pickett Street, Alexandria, VA 22304 


\section{CONTENTS}

\author{
Abstract \\ Introduction \\ Harmon Creek area \\ Geology, soils, and their relation to landsliding \\ Interpretive elements of mass movement between 1939 and \\ 1978 \\ 1939 aerial photographs \\ 1952 aerial photographs \\ 1975 aerial photographs \\ Strip mining and reclamation as related to landsliding
}

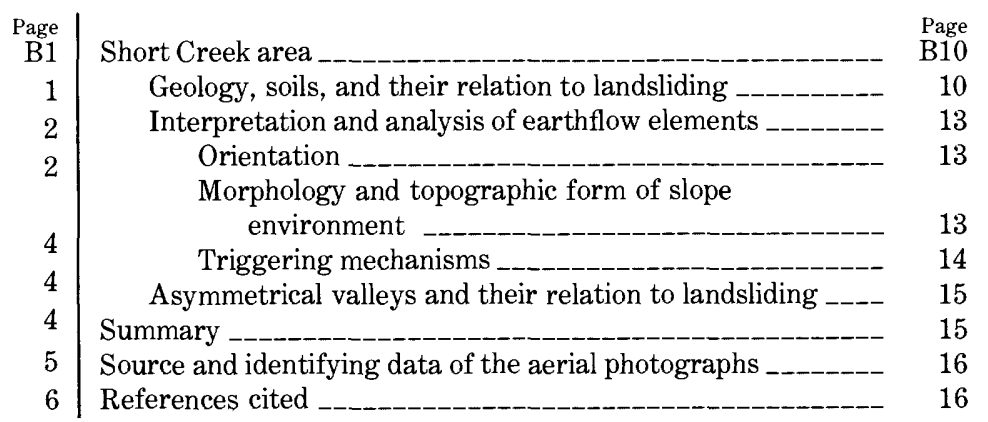

\section{ILLUSTRATIONS}

Frontispiece. Recent earthflows along slopes west of Prosperity, $\mathrm{Pa}$

Page Il

2. Landslide map of part of the Harmon Creek area

3. Photographs of the Harmon Creek area showing old landslide remnant of slumped bedrock, old slump bench adjacent to spoil flow, and reactivated part of old slump bench

4. Block diagram of slump-earthflow

5. Photograph showing slides from regraded spoil-bank surface

6-8. Stereoscopic pairs of aerial photographs showing Harmon Creek valley:

6. 1939

7. 1952

8. 1975

9. Landslide map of part of the Short Creek area

10. Stereoscopic pairs of aerial photographs in the Short Creek area

11-14. Photographs of mass movement in the Short Creek area showing:

11. Recent earthflows along planar northeast-facing slope

12. Head area of reactivated old slide

13. View from old slide surface up toward frontal lobe of recent slide

14. View down recent slide showing older hummocky surface lower on slope 


\title{
MASS MOVEMENT IN TWO SELECTED AREAS OF WESTERN WASHINGTON COUNTY, PENNSYLVANIA
}

\author{
By John S. Pomeroy
}

\begin{abstract}
Two areas, each approximately 12 to $15 \mathrm{~km}^{2}$ (Harmon Creek and Short Creek), show a great amount of mass-movement phenomena typical of western Washington County, Pa. The colluvial slopes are underlain by fine-grained clastic rocks of the Conemaugh and Dunkard Groups of Pennsylvanian and Permian age. In the Harmon Creek area, the Pittsburgh coal bed underlies the hilltops. Strip mining of the coal bed has produced extensive spoil bank and regraded spoil-surface failures. In many places, slumping followed by debris flowage resulted. Movement of rock waste takes place both within the material and at its contact with the natural slope. Also, new and old landslides are abundant on colluvial slopes underlain by red mudstone units approximately $30-80 \mathrm{~m}$ below the coal.

The earthflow is the dominant landslide type in the Dunkard terrain of the Short Creek area and is caused largely by natural forces. More than 75 percent of the recent slides took place on northwest- to east-facing colluvial slopes because of the combination of steeper slopes and greater soil moisture. The most conspicuous orientations are north and northeast. Recent earthflows, varying widely in their morphologic appearance, may be equidimensional, elongated perpendicular to the contour, or elongated parallel to the contour; they commonly take place along concave slopes.

The physical properties of clayey silty landslide material from the two terrains are similar. However, soils derived from the Dunkard Group tend to have a slightly greater proportion of expandable clays, a higher plasticity index, and higher clay content. Clayey silty landslide material from both areas is generally high in porosity but low in permeability and commonly slakes within a short period.
\end{abstract}

\section{INTRODUCTION}

Reconnaissance studies of the six counties constituting the Greater Pittsburgh area have shown that Washington County is the most susceptible to landslides. The region is part of the Allegheny Plateau section of the Appalachian Plateaus province. The Washington County study (Pomeroy, 1976a,b; 1977c) was an extension of an earlier landslide inventory in Allegheny County to the northeast (Pomeroy and Davies, 1975; Briggs and others, 1975) and was conducted in late 1975 and early 1976 after an intensive study of black and white vertical aerial photographs taken in 1975. A map showing landslides and isopleths was a result of the investigation (Pomeroy, 1978).
In early 1978, two arbitrarily chosen areas in western Washington County (fig. 1), each approximately 12 to 15 $\mathrm{km}^{2}$, were examined by means of ground traverses. The purpose of the investigation was to determine the causes and processes of mass movement and the distribution of the landsliding, especially as it related to the geology.

Each area is in a different part of the geologic section. The Harmon Creek area, in the northwestern part of the county, is mostly within the Conemaugh Group of Pennsylvanian age. Red mudstone sequences in the Conemaugh Group produce colluvial or residual soils highly susceptible to sliding in areas to the north and northeast in the Greater Pittsburgh region (Pomeroy and Davies, 1975; Briggs and others, 1975; Pomeroy, 1977a, b) and to the south, southwest, and west in West Virginia (Lessing and others, 1976) and southeastern Ohio (Fisher and others, 1968).

Furthermore, the Pittsburgh coal bed crops out in the Harmon Creek area and has been extensively strip mined since the 1940's. Many slides originating from strip mining have compounded the hazards of naturally unstable slopes. Aerial photographs taken over a period of years from 1939 to 1975 document the formation of landslides resulting from strip-mining activities.

The Short Creek area in the southwestern part of the county was selected because it is typical of southern Washington County terrain. The combination of steep slopes and unstable colluvial or residual soils derived from gray to greenish-gray claystone and mudstone of the Dunkard Group of Pennsylvanian and Permian age is responsible for southern Washington County possessing the highest density of slides in the Greater Pittsburgh region (Pomeroy, 1977a). Most slides are of the earthflow type. Many landslides largely in Dunkard Group terrain in adjacent areas of Washington County were delineated on geologic quadrangle maps and were briefly discussed by Kent and others (1969) and Berryhill and others (1971). No attempt was made to use older photographs to supplement the 1975 aerial photography 

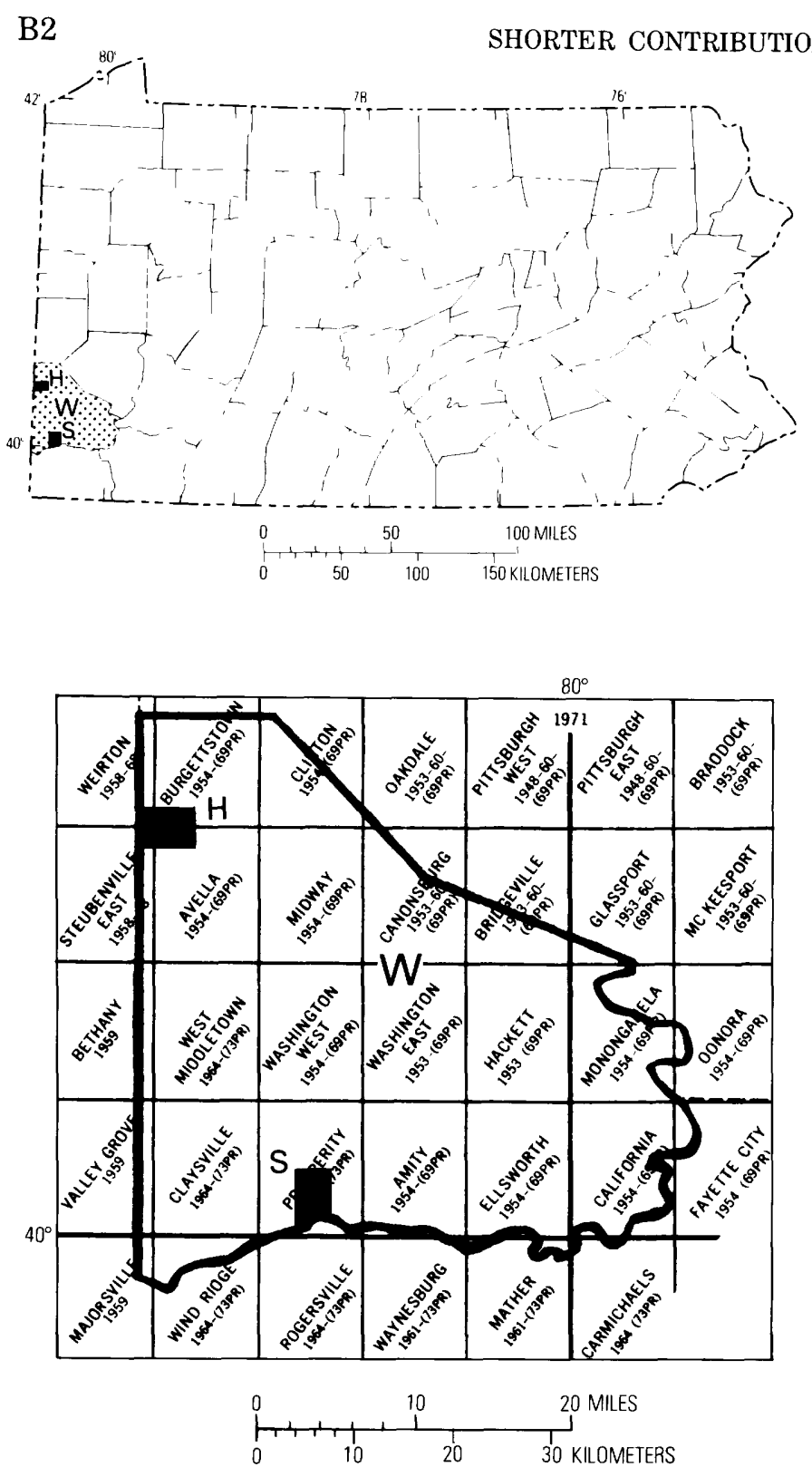

EXPLANATION

W Washington County

$\mathrm{H}$ Harmon Creek area

S Short Creek area

Figure 1.-Index maps of Pennsylvania showing location of Washington County, Harmon Creek area, and Short Creek area. The lower map is from U.S. Geological Survey index to $7 \frac{1}{2} 2$-minute topographic quadrangles in Pennsylvania.

because the area has not undergone as much of a change as has the Harmon Creek area.

Figures 2 and 9 show recent and old landslides. In addition to currently active slides, the term "recent" includes those slides that are believed to have been active within the past century. Recent landslides may be shown as discrete individual bodies, but, in some places, a large number of closely spaced (and overlapping) slides are mapped as one unit.

Although old landslides are commonly represented as individual slides, most areas shown as old landslides represent a series of coalesced slides that cannot be distinguished from one another. Old aggregates of slides involve multiple periods of mass movement that Carbon-14 dates from old landslides at construction sites in the Upper Ohio valley (D'Appolonia and others, 1967; Philbrick, 1962), indicate probably took place during the Pleistocene and postglacial times.

Because the documentation commonly is lacking, the separation of "recent" from "old" slides is difficult. Some slides mapped as "old" might actually have moved within the past century, but erosion and revegetation have masked their features. Old slides generally lack a clearly definable head scarp but can be recognized by the characteristic hummocky ground along the lower slope.

The word "landslide" has been widely used as an allinclusive term for almost all types of slope measurements and is so used here. The contributors to a recent volume on landslides (Coates, 1977) agreed that movements involving falling, sliding, and flowing could be included as landslides.

The author acknowledges the assistance of K. S. Donovan, Monique Moore, and Brad Kauffman, who performed physical-properties tests under the supervision of S. F. Obermeier, and of Susan Nabb and Melodie Hess, who conducted and interpreted X-ray diffraction tests.

\section{HARMON CREEK AREA \\ GEOLOGY, SOILS, AND THEIR RELATION TO LANDSLIDING}

The Harmon Creek area as discussed in this report lies within parts of the Avella, Steubenville East, Burgettstown, and Weirton 71/2-minute Quadrangles (fig. 1) and is approximately $6 \mathrm{~km}$ west of the town of Burgettstown, $\mathrm{Pa}$. The average relief is about $130 \mathrm{~m}$. The part of the Harmon Creek area in the Avella $7 \frac{1}{1} 2$-minute Quadrangle is shown on figure 2.

The Avella and part of the Steubenville East 71/2-minute Quadrangles were mapped by Schweinfurth (1976) as part of a coal-investigation project in Washington County during the 1960's. Stratigraphic sequences in the Harmon Creek area are cyclic and include the Glenshaw and Casselman Formations of the Conemaugh Group (Pennsylvanian), the Pittsburgh and Uniontown Formations of the Monongahela Group (Pennsylvanian), and the basal part of the Waynesburg Formation of the Dunkard Group (Upper Pennsylvanian and Lower Permian). The Pittsburgh coal, at the base of the Monongahela Group, occurs near the top of hills in the area and has been extensively exploited. The bedrock is almost horizontal and dips less than $1^{\circ}$ to the 

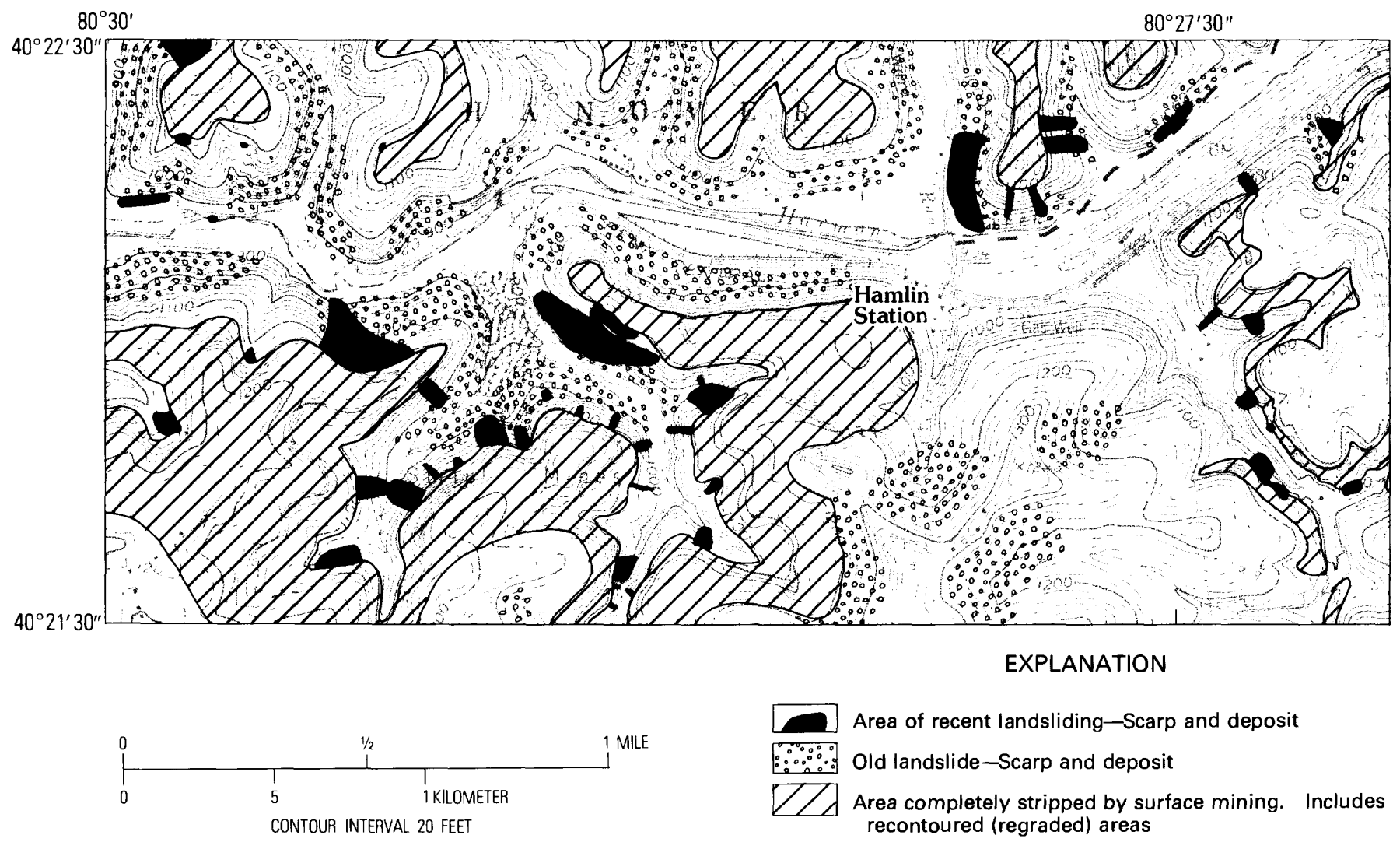

Figure 2. - Landslide map of that part of the Harmon Creek area in the Avella 71/2-minute Quadrangle, Washington County, Pa.

southeast. Natural outcrops along the slopes above Harmon Creek are uncommon. Exposures are found along access (haul) roads leading to the Pittsburgh coal and in areas where railroads cut into the lowermost slopes.

The Conemaugh Group is poorly exposed along Harmon Creek and its tributaries. Rocks of the Conemaugh Group include poorly bedded variegated gray, tan, green, to maroon mudstone interlayered with claystone, shale, siltstone, sandstone, and minor limestone. The red mudstone units, commonly containing claystone interbeds, are of varying thickness and highly susceptible to landsliding where weathered. Red mudstones correlative with the "Pittsburgh red beds" of the Glenshaw Formation (Pomeroy and Davies, 1975; Pomeroy, 1977a) underlie the lowest slopes of Harmon Creek and its tributaries in the western part of the area shown in figure 2. Red mudstones identifiable in stratigraphic position with the "Clarksburg red beds" of the Casselman Formation (Pomeroy and Davies, 1975; Pomeroy, 1977a) occupy slopes in the central and eastern parts of the area shown in figure 2.

The soils of the Harmon Creek area are the same as the unstable Gilpin-Upshur-Vandergrift soils derived from the Conemaugh Group of Beaver and Allegheny Counties to the north and northeast (Pomeroy and
Davies, 1975; Pomeroy, 1977b; U.S. Soil Conservation Service, 1973a, b). The Soil Conservation Service has recognized that slopes along Harmon Creek and some tributaries are largely slumped, and the word "slumped" is included in the description of the mapped unit (U.S. Soil Conservation Service, 1974a, b). Samples of red clayey to clayey silt soil from 11 landslide localities in this and and adjacent areas indicate a moderate to high plasticity index ranging from 8 to 31 and averaging 18 and an average particle-size distribution of 26 percent sand, 47 percent silt, and 27 percent clay. X-ray diffraction analyses revealed that the clays consist of a higher percentage of illite-kaolinite than of vermiculite and interlayered minerals. The clayey material slakes readily and possesses a high porosity but low permeability.

Bedding of outcrops on some slopes (fig. $3 A$ ) is tilted back toward the slope at an angle much steeper than the regional subhorizontal dip. Local exposures that have steeply dipping beds are interpreted to be ancient rotational slump blocks. Other indicators of ancient landslides include hummocky ground surfaces and less obvious narrow terraced areas or benches along hillsides (fig. $3 B$ ). These geomorphic features represent colluvial materials from previous sliding episodes that are occasionally subject to reactivation (fig. $3 C$ ); some are not 
apparent on the topographic map. Benched areas in forested land may be only a few meters wide (fig. $3 B$ ) and are commonly discontinuous. Thus, some cannot be identified on the aerial photographs.

Characteristic of most large old landslides are their origins from concave (laterally and longitudinally) or bowl- or amphitheater-shaped slopes, which, owing to surface- and ground-water concentrations, are wetter than adjacent areas. Old landslides have also been detected along planar slopes on both sides of Harmon Creek. Distinctive bowl-shaped slopes are present above the Pittsburgh coal along colluvial slopes south of Hanlin Station (fig. 2). These features are thought to be detachment scars of old landslides.

Small (less than $15 \mathrm{~m}$ wide) modern-day landslides, mostly slump-earthflows (fig. 4) take place in soils derived from red mudstone and claystone along slopes bordering Harmon Creek. These landslides combine the process of sliding and flow. The upper part slides downward by rotational slip (slump); the lower part moves as a viscous flow (earthflow). In the past, most slides were probably due to natural causes (precipitation and stream-bank undercutting) before the area was strip mined. Since the strip mining, most slides have originated as spoil-bank failures, slumps along hastily constructed access roads, and regraded spoil-bank areas (fig. 5) adjacent to steep slopes.

Irrespective of the spoil-bank slides caused by strip mining and the probable old landslides above the Pittsburgh coal horizon, most recent and older sliding is concentrated in that part of the geologic section approximately $30-80 \mathrm{~m}$ below the Pittsburgh coal horizon where red mudstone is common (fig. 2). Landslides originating from the $0-30 \mathrm{~m}$ stratigraphic interval below the Pittsburgh coal horizon are uncommon. For example, this interval along the access road from Hanlin Station to the hilltop immediately to the north is underlain mostly by interbedded gray to greenish-gray mudstone, shale, siltstone, and minor thin-bedded sandstone. No small slides or slips were noticed in colluvium derived from this material in this locality.

Mass-movement features shown in selected aerial photographs (figs. 6-8) are discussed. Any area identified as an old landslide has been confirmed by field inspection. Not all features discussed are discernible on the aerial photographs.

\section{INTERPRETIVE ELEMENTS OF MASS MOVEMENT BETWEEN} 1939 AND 1978

1939 AERIAL PHOTOGRAPHS (FIG. 6)

Areas marked $a$ represent old landslides characterized by a hummocky surface and moderate grade on the lower slopes. A break in the topography commonly marks the location of the head of an ancient slumpearthflow as revealed by the benching at an old landslide above the north-south road in the eastern part of the area shown in the figure. Some bowl-shaped slope surfaces are more diagnostic of old landslides than are lower slope surfaces, which may be masked by dense vegetation. Planar to convex old landslides $(b)$, where small narrow terraces or benches are present on at least three distinct levels on each slide, had not been identified before the field examination.

Coal refuse dumps $(c)$ are composed of waste from local deep-mining operations located near the hilltop. An interesting note is that, earlier in the century, mine waste was not dumped at the level of the mining activity but instead was transported to small dumps, which were generally stable.

The rockfall hazard $(d)$ was present only in outcrop areas along man-cut slopes above the railroad. Rockfalls are produced by weathering and erosion, which affect mudstone and shale more readily than they do sandstone, siltstone, and limestone. Only a few years need elapse before unsupported ledges of the more resistant rocks break away by falling. Jointing is a significant factor.

Slides $(e)$ were obviously caused by precipitation and took place in the $28-36 \mathrm{~m}$ interval below the Pittsburgh coal.

An earthflow $(f)$ lies within an old landslide and involves approximately the same interval as that shown at $e$. Note the recent slide at $g$ which can be seen on the 1952 photographs ( $c$ on fig. $7 B$ ).

Summary. Before extensive strip mining, this sparsely populated area was subject to landsliding in colluvium derived from red mudstones. Nearly all slides shown in this particular stereoscopic pair (fig. 6) are assumed to have been caused by precipitation. The lower halves of slides designated $e$ and $f$ are inferred to be underlain by red mudstone on the basis of a nearby measured section.

\section{AERIAL PHOTOGRAPHS}

Strip mining was a radical change in land use. The obvious mine-waste slides shown on figure $7 A$ rarely exceed $30 \mathrm{~m}$ in length and stop short of the hummocky less steep lower slopes $(a)$ indicative of old landslides (1939 photographs), except in extensive slide area $(b)$. The slides appear to be relatively shallow and reflect a failure of zones within the spoil material itself or at the spoil material-colluvium interface. The largest individual slide exceeds $6,000 \mathrm{~m}^{2}$. Harmon Creek has been diverted by the emplacement of slag and mine waste $(c)$.

Old landslide surfaces $(\alpha)$ shown on figure $7 B$ can be seen on 1939 photographs. The surfaces of the probable old landslides $(b)$ are underlain by unstable soil (U.S. Soil Conservation Service, 1974b) derived from the 

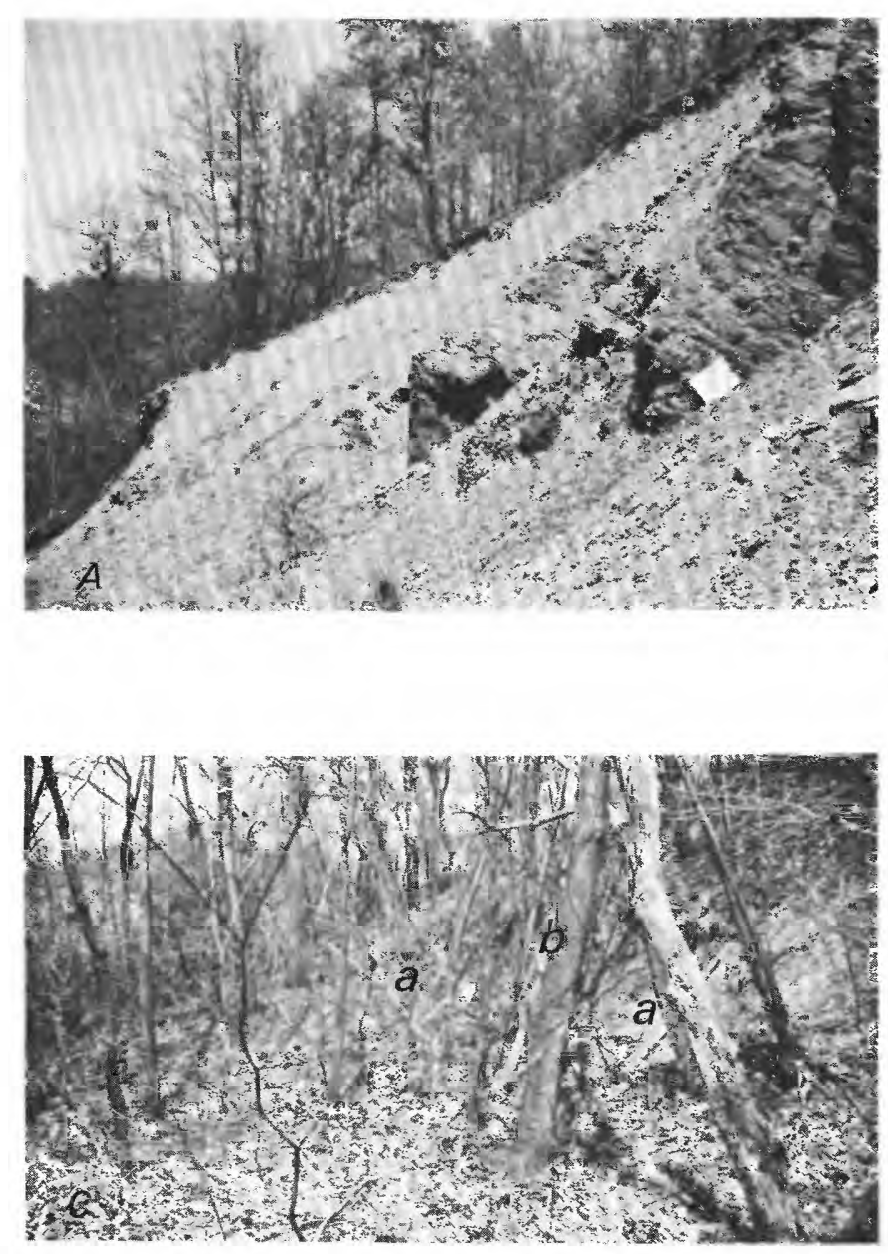

Monongahela Group. A recent slide $(c)$ was evident in the 1939 photographs ( $g$ on fig. 6). Vegetation has not covered this slide, probably because of the periodically renewed soil movement.

\section{AERIAL PHOTOGRAPHS}

In Figure $8 A$, an access road to the top of the hill traverses the slumped area seen on earlier photographs and has both directly and indirectly caused many new slides $(\alpha)$ in colluvium derived from red mudstones in the Casselman Formation. Obvious spoil-bank slides in 1952 are just faintly discernible 23 years later $(b)$. The top of hill has been reclaimed (regraded), and spoil material has slumped $(c)$ and flowed downslope. Bedrock ledges examined in the field are exposed by subsequent gullying halfway down the slope. Fresh scarps in red soil along the hummocky lower slope $(d)$ adjacent to the slide have formed because of the additional weight of the transported material in addition to drainage changes diverting water to the hummocky area. This area is one of several old landslide areas where benching is more apparent on the 1939 photographs before surface mining

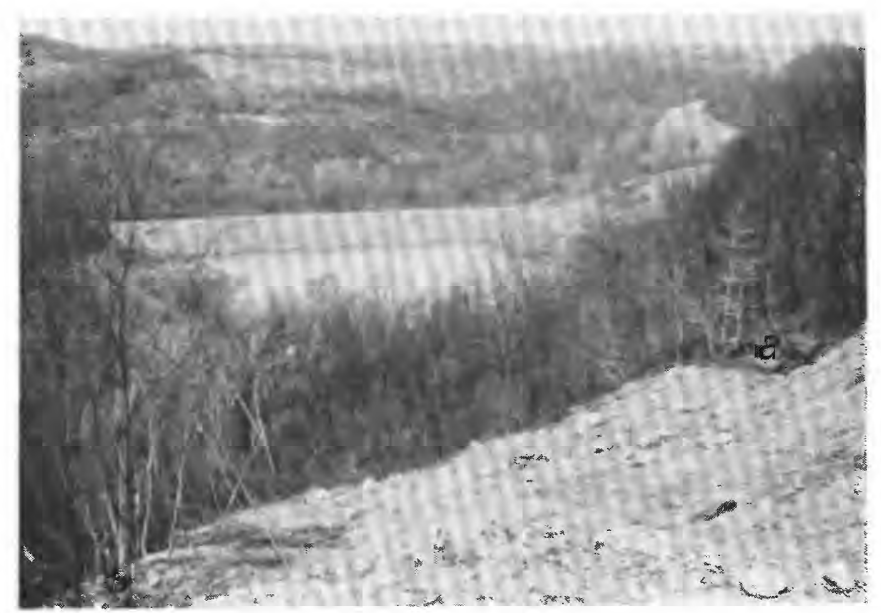

Figure $3-A$, Old landslide remnant of slumped bedrock. $B$, Old slump bench adjacent to spoil flow; note flattening of slope $(a) . C$, Reactivated part of old slump bench; note head scarp $(a)$ and tilting of trees $(b)$ produced by slumping.

was begun. Part of an obvious 200-m-wide old landslide (e) has been reactivated (fig. 5 , foreground) by post- 1975 surface mining. Planar slope $(f)$ shows small recent slump-earthflows in red mudstone colluvium above the road. The dissected slope is wet where seeps appear at the slight break in slope $(g)$.

Obvious flow $(h)$ along a planar slope below a regraded area shown in this 1975 photograph was grass covered in 1978, and the head scarp was still discernible. Areas (i) show well-defined flow movements originating from the edge of the regraded surface. An old surface ( ), though not reactivated in 1975 , showed a recent wasterock flow when examined in the field in 1978. Slumping and flowage of regraded rock waste have taken place in area shown at $k$.

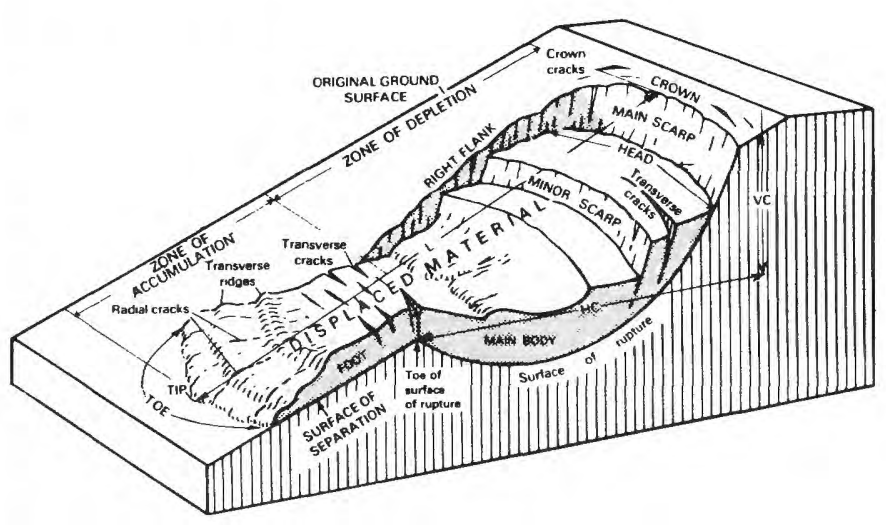

FIGURE 4.-Block diagram of slump-earthflow (from Varnes, 1978). HC, horizontal component; VC, vertical component; L, length. Note: A simple earthflow does not show slumping. 


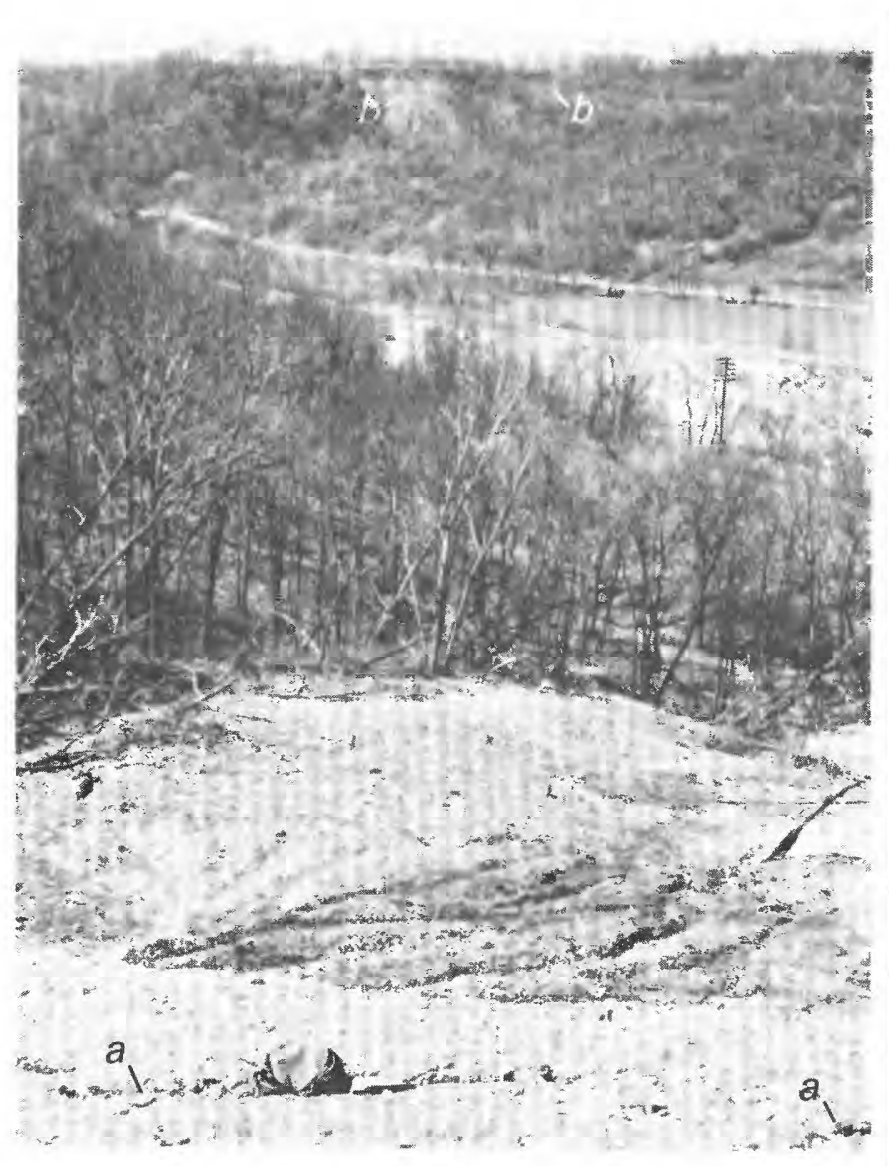

Figure 5. - Slides originating from regraded spoil-bank surface. Cracks $(a)$ above head scarp indicate future retrogressive development. Slides in background (b) are simliar to slide in foreground.

The major recent landslide at $a$ on figure $8 B$ took place after 1969, as determined by an analysis of 1969 photographs. The slide in colluvium, largely derived from red mudstone, was nearly $450 \mathrm{~m}$ wide, as seen in this photograph, but has since extended several tens of meters to the southeast. The terminus of the slide is outlined by a frontal margin of partially transported trees inclined in several directions; small ponds and cattail marshes are behind them. Sliding of the reclaimed (recontoured) surface $(b)$ has taken place above the access road. The diversion of drainage caused by the road to the hummocky slope of the old landslide (figs. $6,7 \mathrm{~A}$ ) has contributed to extensive reactivation downslope. Area $(c)$ south of the newly constructed dam, was terraced after the landsliding that took place sometime after 1969. On earlier photographs (figs. 6, 7A), this convex slope showed natural benches indicative of earlier sliding. The hummocky lower slope of largely red mudstone colluvium at $d$ was locally reactivated near the reservoir, partly because of tree removal. Most of the slides sharply defined on the 1952 photographs (fig. 7A) are no longer discernible at $e$. New and enlarged failures at $f$ took place after regrading.

\section{STRIP MINING AND RECLAMATION AS RELATED TO LANDSLIDING}

We know that spoil-bank failures in the Harmon Creek area took place between 1939 and 1952 because 36 spoilbank slides were identified on the 1952 aerial photographs. Between 1952 and 1969 only two of these slides were significantly enlarged, and no new slides took place. The 1975 photographs show extensive stripmined areas that have been reclaimed by regrading the spoil to the approximate former configuration of the land surface. Only one spoil-bank failure had taken place during the 1969-1975 period, but 15 slides had formed along the edge of the restored surface. During or after reclamation, two large areas of sliding ( $\alpha$ on fig. $8 A, B$ ) were caused by roadbuilding, which deflected drainage onto the sensitive slopes. Field inspection in early 1978 revealed one new massive slide in a recently stripped area ( $e$ on fig. $8 A$ ) and another slide in a regraded section ( $j$ on fig. $8 A$ ).

In summary, 38 slides resulted from spoil-bank failure, 16 slides formed at the edge of the regraded spoil surface, and two large areas of sliding resulted after more extensive slope-cut and fill operations were made to accommodate the transportation of large earth-moving machinery for regrading.

An analysis of the spoil-bank slides shows that most of the slides took place along planar slopes (only 14 of the 36 slides appeared along concave slopes, including heads of tributary valleys). All affected slopes were at least 35 percent grade $\left(20^{\circ}\right)$, and a few were almost 80 percent grade $\left(39^{\circ}\right)$, the average was about 60 percent grade $\left(31^{\circ}\right)$. Two-thirds of the regraded spoil-surface slides, however, took place along concave and generally less steep slopes.

The influence of the underlying slope to the spoil-bank failures cannot be precisely determined without subsurface instrumentation. However, movement of most rock-waste slides is believed to have taken place within the waste-bank material itself or at the contact between the spoil and the colluvial surface of the slope. Little firm evidence was found to indicate that the underlying colluvium moved as the result of the overloading of the slope by rock waste. However, a few slide areas 1.0-1.3 $\mathrm{km}$ west and west-southwest of Hanlin Station (fig. 2) include slightly hollowed-out surfaces, which imply the removal of subjacent slope colluvium. In this area, either nearby outcrops of red mudstone (less than $2 \mathrm{~m}$ thick) above manmade benches or small amounts of red soil within $30 \mathrm{~m}$ of the Pittsburgh coal horizon are indicators of conditions that are conducive to soil movement. Sur- 


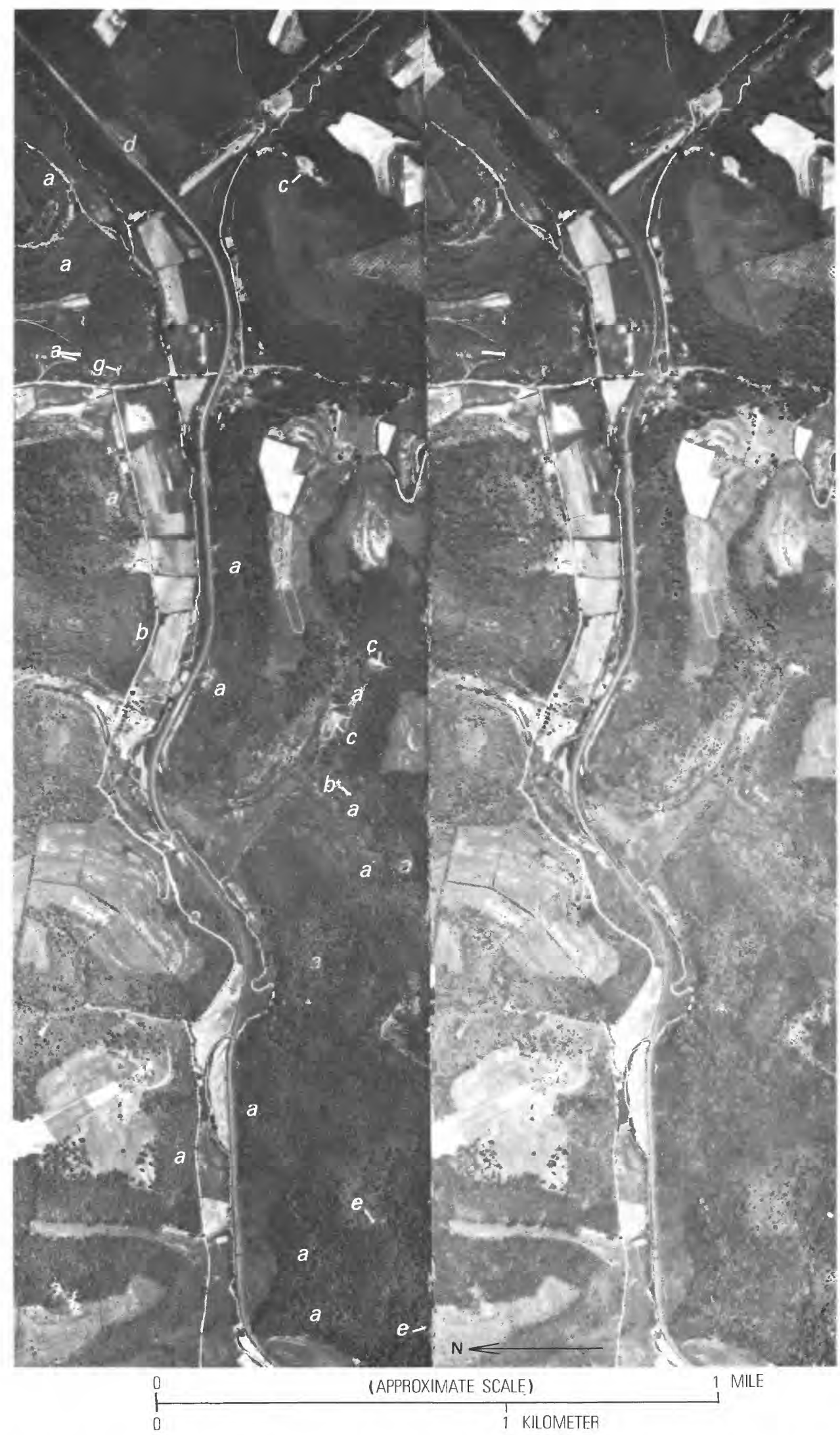

Figure 6. -Stereoscopic pair of Harmon Creek valley, Washington County, Pa., 1939. Explanation of letters given in the text. 


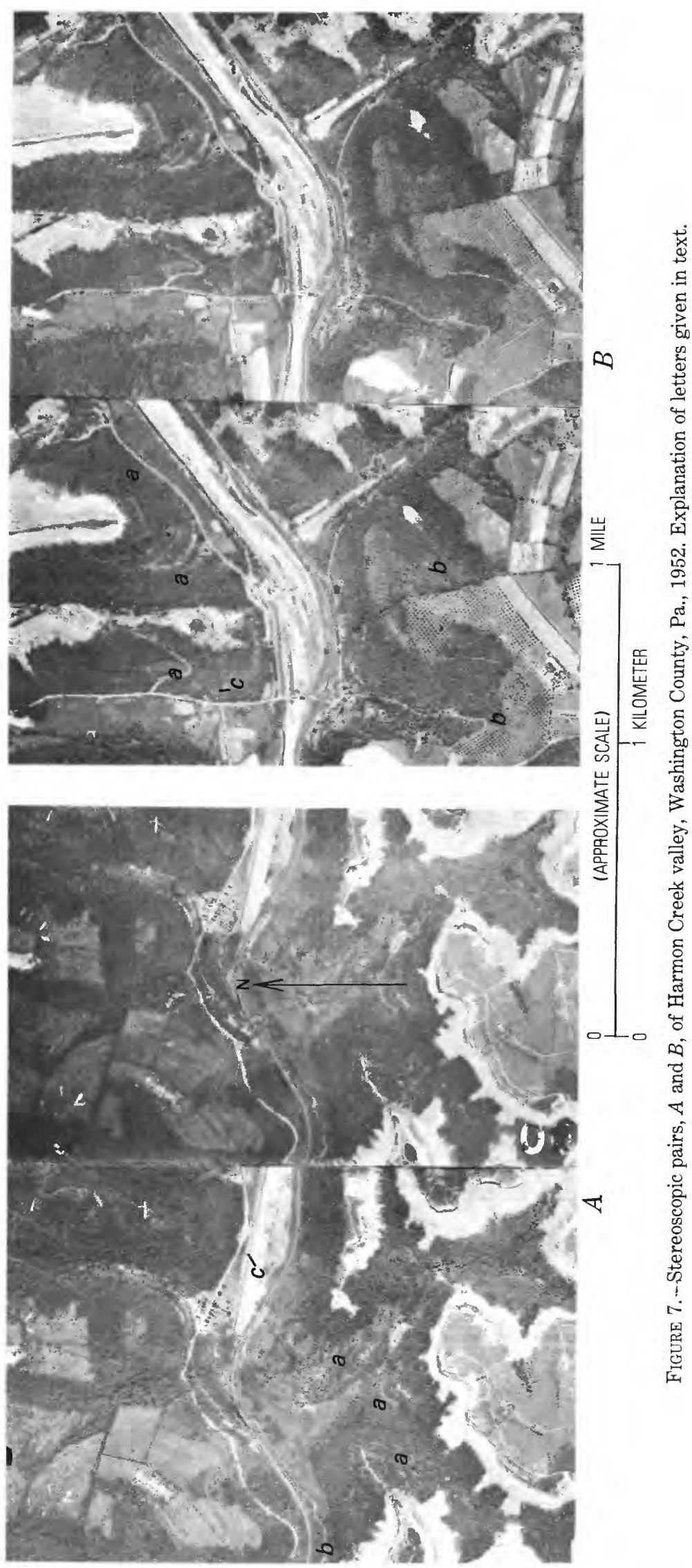




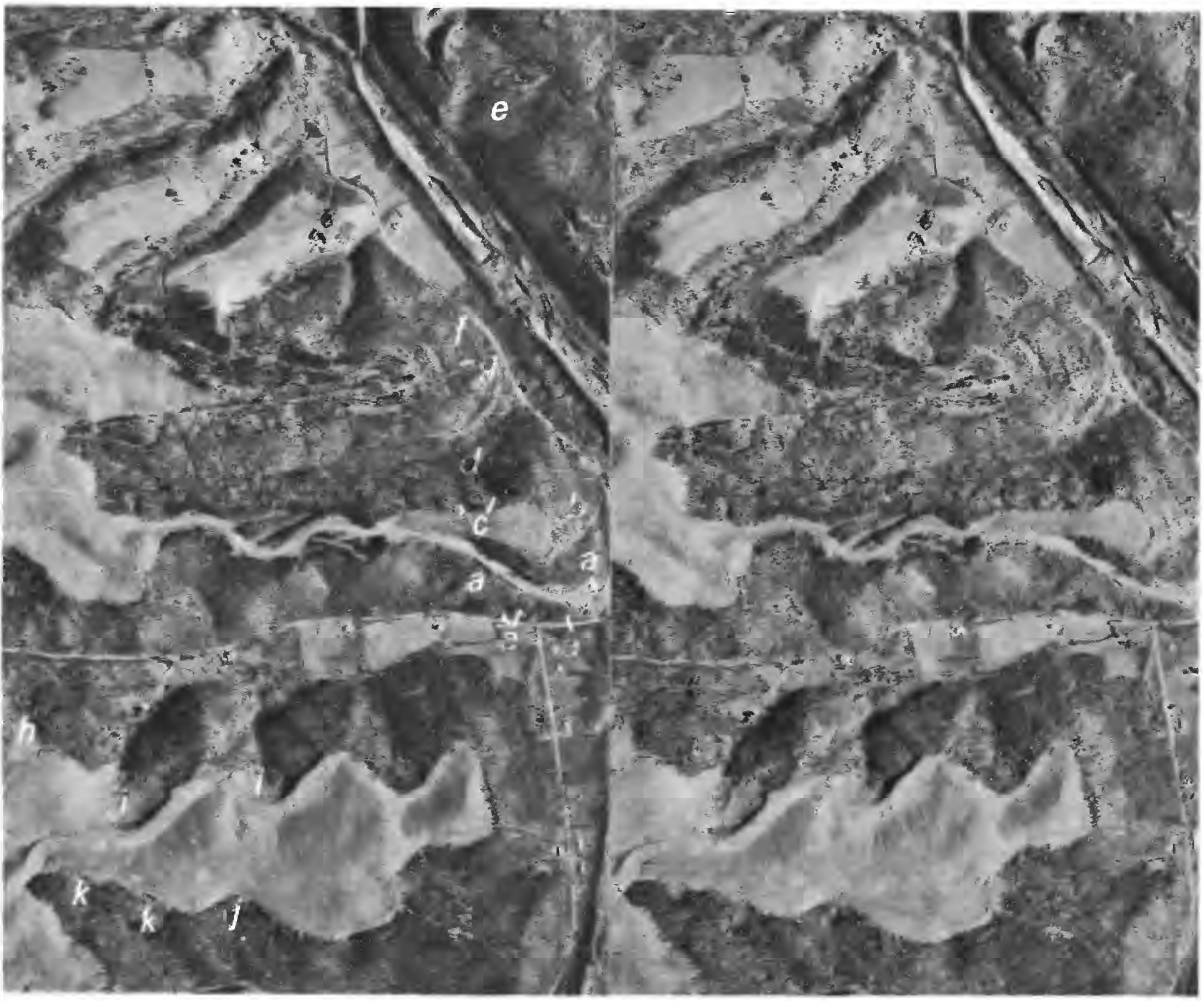

A

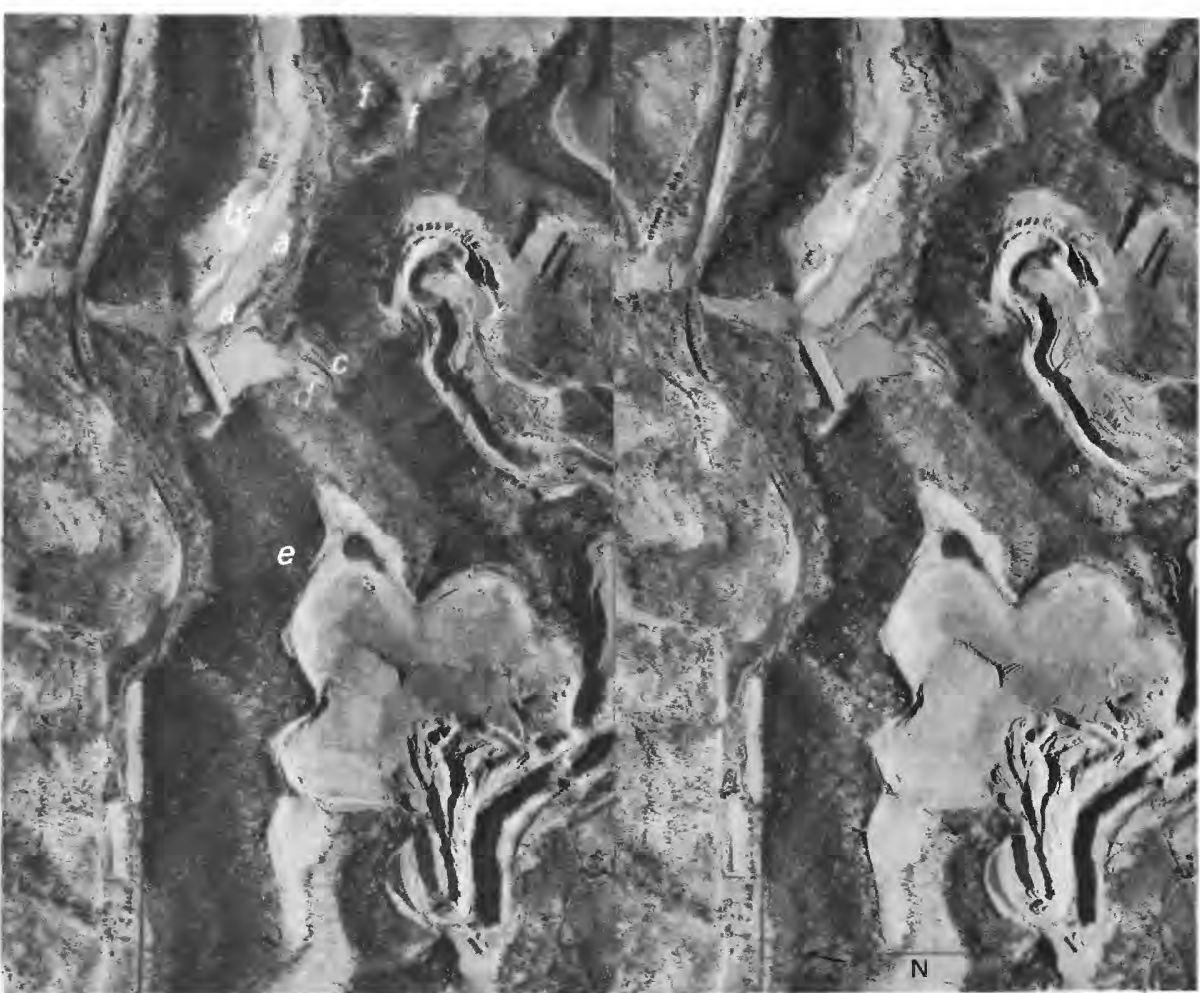

B

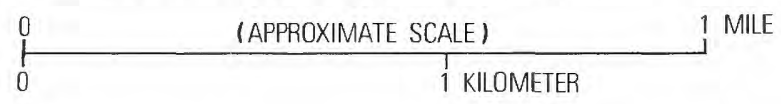

Figure 8. Stereoscopic pairs, $A$ and $B$, of Harmon Creek valley, Washington County, Pa., 1975. Explanation of letters given in text. 
charging of the slope by rock waste in these areas leads to failure.

The presence of tension cracks behind the edge of the spoil is the first sign of impeding failure especially where the cracks are more than $0.1 \mathrm{~m}$ wide and show obvious vertical displacement. The cracks serve as incipient failure surfaces and act as conduits for surface water penetrating the fill.

Increased crack widening and vertical displacement along cracks lead to slumping caused by slip-plane formation due to decreased shear resistance. Continued rotational movement further breaks up the surface, and small blocks are formed. Both increased precipitation over a long period of time and sudden intense downpours can lower shear strength of the material. The increased load and the decreased shear strength of slope material result not only in slumps but also in debris flowage onto lower slopes.

In many areas affected by mine spoil, the initial massmovement process is due to a stacking of too much poorly consolidated spoil material along the bench edge. The instability of this configuration is compounded by a lack of adequate surface-runoff control (Zook and Bednar, 1975; Kimball, 1974). The mining of coal beds near the tops of the hills has led to the removal of entire hilltops. The overburden has been dumped indiscriminately both into the heads of reentrant valleys and onto divergent slopes. Ponds are formed on the flattened spoil surfaces and contribute to the adjacent outslope saturation. Detailed engineering investigations, in which appropriate instruments (piezometers and slope indicators) and observation wells at specific monitoring sites are used, would help in defining future problem areas.

\section{SHORT CREEK AREA}

\section{GEOLOGY, SOILS, AND THEIR RELATION TO LANDSLIDING}

The Short Creek area lies within the Prosperity $71 / 2$-minute Quadrangle in southwestern Washington County and has an average relief of approximately 120 $m$. The village of Prosperity is in the extreme northeast corner of the area, nearly $15 \mathrm{~km}$ south of the city of Washington, $\mathrm{Pa}$. Although the Prosperity 71/2-minute Quadrangle has been geologically mapped and mass movement was clearly recognized by Kent (1972), landslides were not shown because their representation would have obscured the bedrock map units.

The poorly exposed bedrock consists of nearly flat lying cyclic sequences of sedimentary rocks belonging to part of the Dunkard Group of Permian age. The Greene Formation underlies all the area shown in figure 9 except for the drainages northwest of Sparta and in the northeast corner of the area shown on the map, where the uppermost part of the Washington Formation crops out. The Greene Formation consists chiefly of mudstone, siltstone, sandstone, and thin lenticular persistent beds of limestone, claystone, shale, and coal. Regionally, bedding dips less than $1^{\circ}$ toward the southeast (Kent, 1972).

Soils having a moderate to high shrink-swell potential are present over most of the area and have been included in the Guernsey-Culleoka series (U.S. Soil Conservation Service, 1974b). Although individual soil-slip symbols are sparingly used on the Soil Conservation Service photo maps, extensive slumped areas as wide as $3.5 \mathrm{~km}$ (the slope south of Short Creek) are denoted. The present study generally confirms the interpretation shown on the soil maps.

The Washington County isopleth map (Pomeroy, 1978) shows 40-70 percent of the Short Creek area covered by landslide scars and landslide deposits. Landslides take place commonly in colluvial or residual clayey to clayey silt soil and highly weathered rock derived from mudstone, claystone, limestone, and shale. Samples of landslide material from the Short Creek and adjacent areas indicate a moderate to high plasticity index, ranging from 10 to 28 and averaging 21 ; average particle-size distribution is 22 percent sand, 46 percent silt, and 32 percent clay. X-ray diffraction studies revealed that the clay consists of, in decreasing order of abundance, illite, vermiculite, kaolinite, and interlayered minerals. The clay slakes rapidly and is characterized by relatively high porosity and low permeability.

Earthflows and slump-earthflows (fig. 4), the dominant landslide types in the area (fig. 10), consist of soil and weathered rock that are rarely more than $3 \mathrm{~m}$ thick. Evidence of slumping is common in the head area. Earthflows are crescent-shaped, rectangular, or oval bodies often found along sloping pasture land and less often in forested areas. Earthflows range in size from a few meters to several tens of acres; most are less than a quarter of an acre. Scarps of earthflows may heal in less than 10 years, but the hummocky slopes indicate centuries of former slope movements. Sharpe $(1938$, p. 55) observed that many hills in eastern Ohio, West Virginia, and western Pennsylvania are "scarred by thousands of old earthflows, and almost the entire surface of certain slopes show the typical scarps and hummocks of former movements."

Unmappable small-scale slumping is typically expressed in the form of "cattle terraces" or "catsteps" produced by animals' hoofs cutting into the hillslope. Scars are produced on the uphill side of repeatedly used paths. These features are significant in the distribution of surface runoff to various parts of a slope and influence the siting of larger slides. 


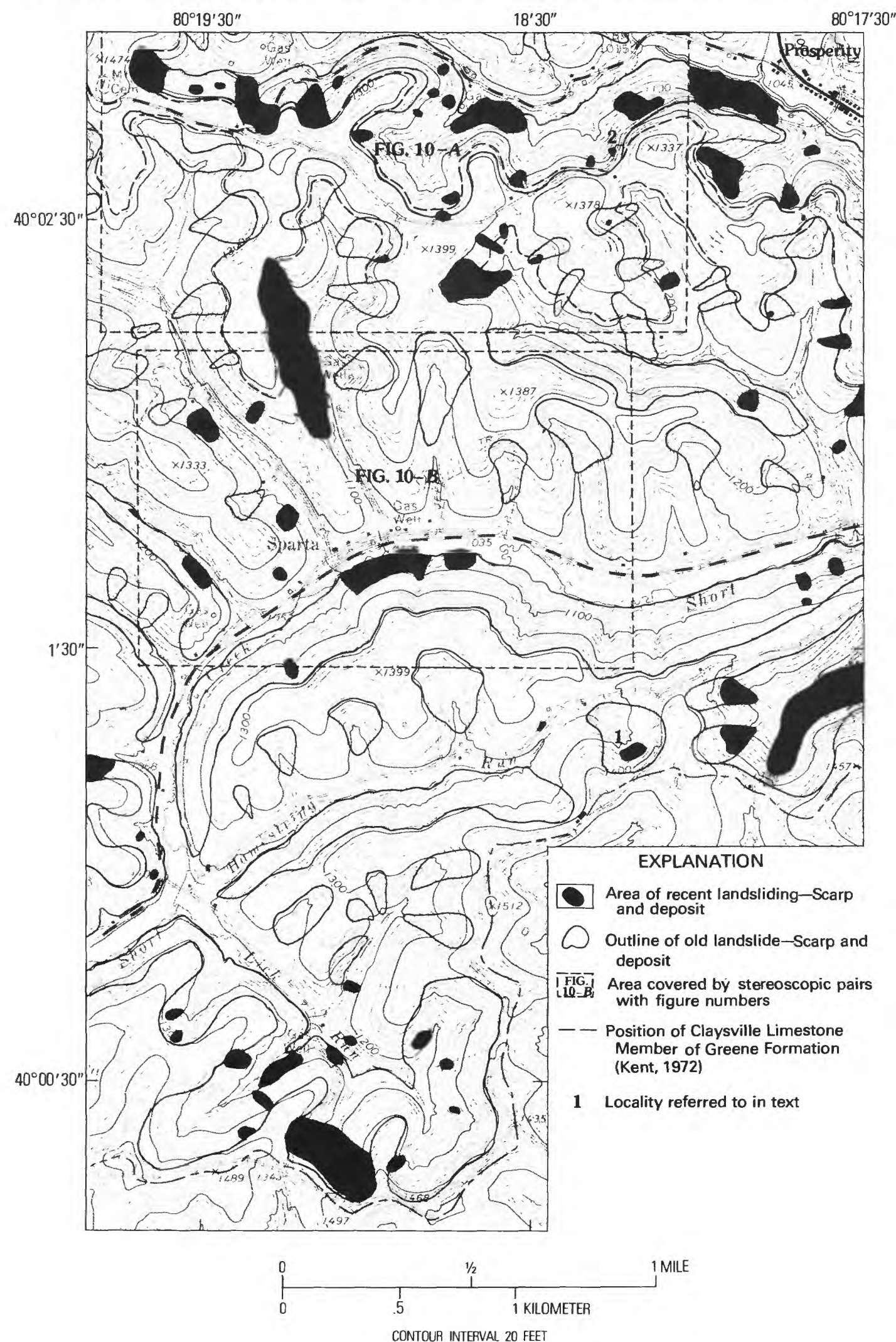

Figure 9. - Landslide map of part of the Short Creek area, Pa. 


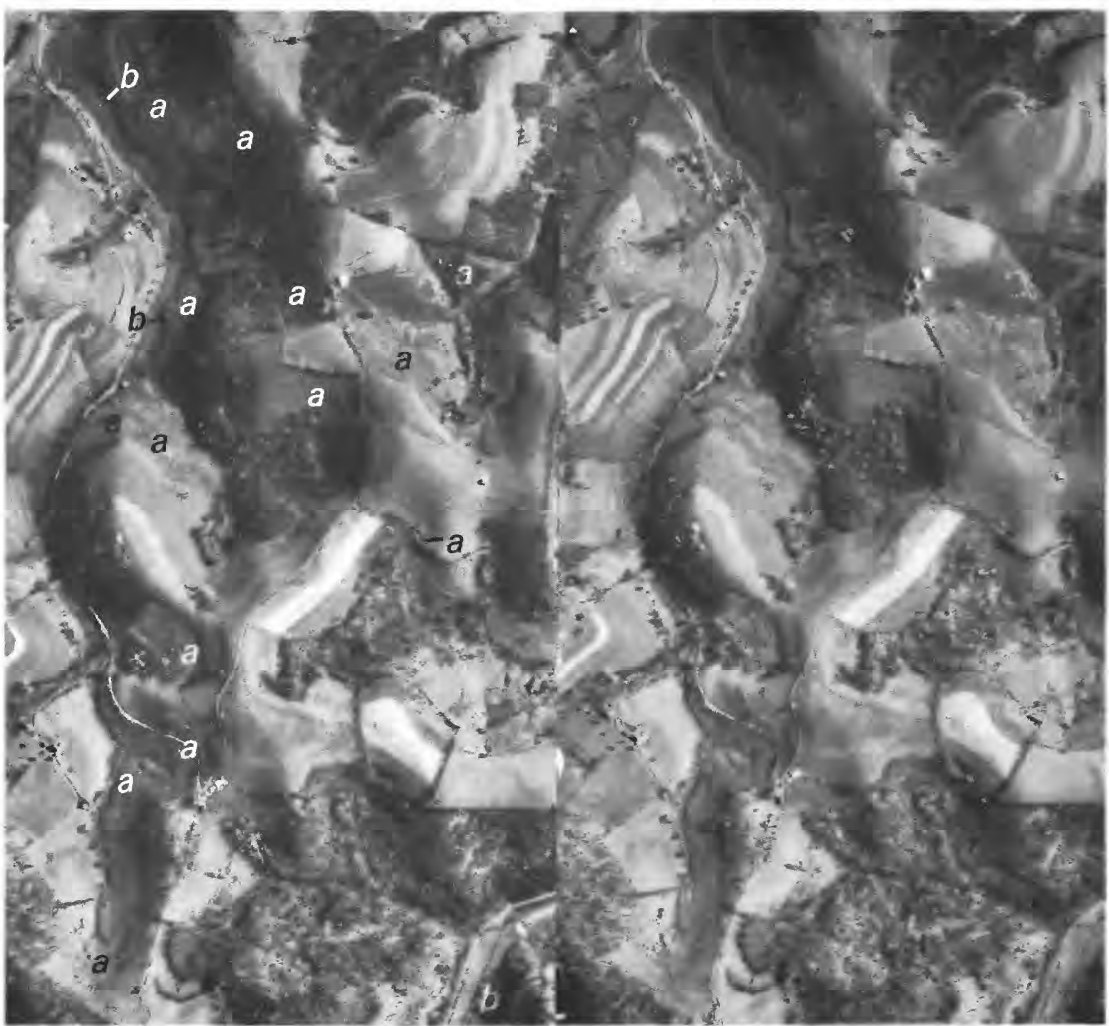

A

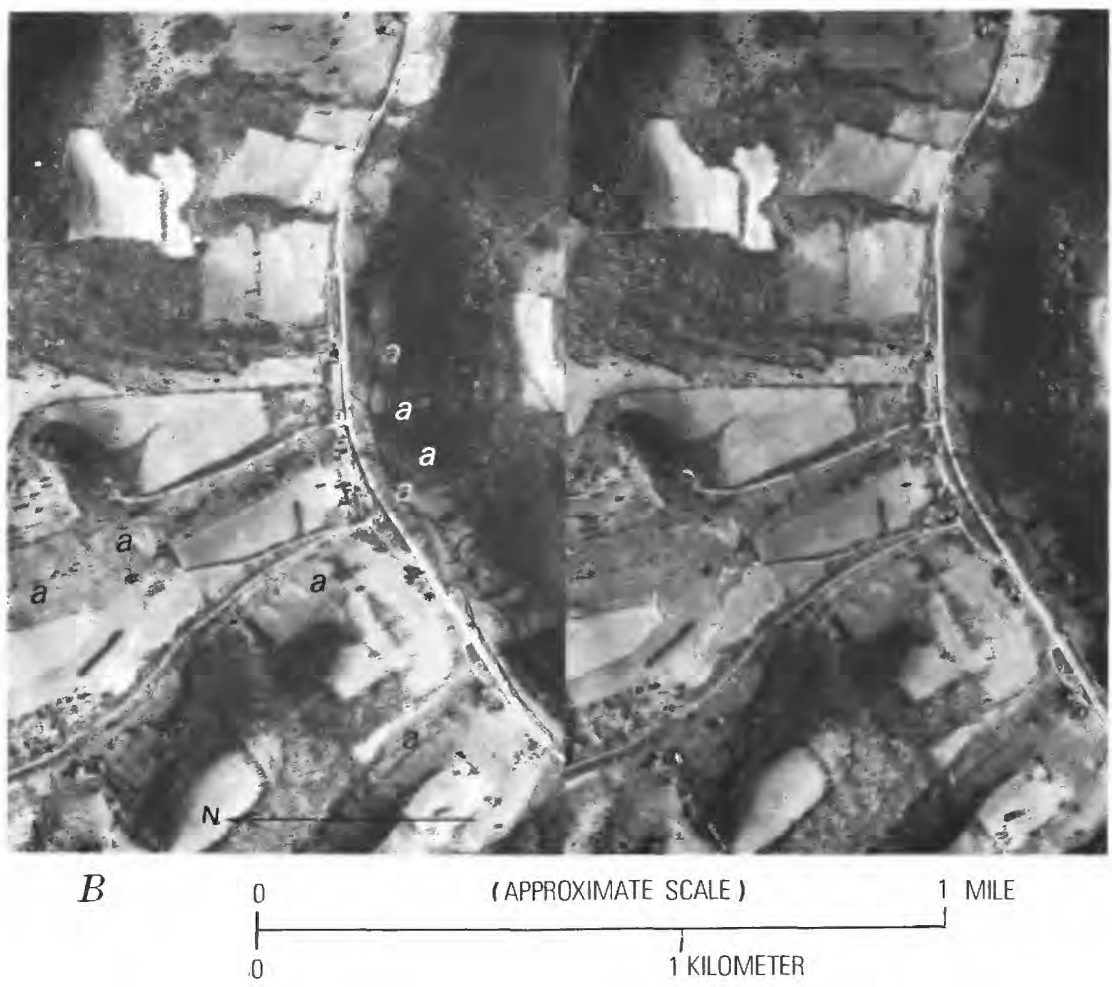

Figure 10.-Stereoscopic pairs of the Short Creek area, Washington County, $\mathrm{Pa}$. A, Terrain west of Prosperity, Pa. Note the affinity of recent active earthflows $(a)$ for concave northwest- north- northeast- and east-facing slopes. Note abrupt terminal margins $(b)$ of old landslides. $B$, Short Creek Valley. Note the asymmetric valley formation. Many episodes of old to recent sliding have occurred along the steep north-facing slope bordering the east-trending Short Creek. Recently active earthflows $(\alpha)$ commonly show a strong preference for wetter north- to east-facing slopes. Note the recent slides on all configurations of slope surfaces. Note the frontal margins of old slides, especially along Short Creek. 
Most failure surfaces in earthflows appear to originate at or close to claystone beds that might underlie a limestone or be part of a mudstone sequence along a $15-40$ percent grade slope $\left(9^{\circ}-22^{\circ}\right)$. Commonly, slopes show an overlapping sequence of earthflows largely controlled by a cyclical repetition of claystones. Kent (1972), Kent and others (1969), and Berryhill and others (1971) recognized the correlation of landslides with largely impervious limestone. Seeps are common at the contact between an impermeable unit and overlying permeable siltstone or sandstone. Thus, stratigraphy controls the wetting of lower slopes and the occurrence of earthflows. Impervious layers are affected by a marked increase in pore-water pressure during saturation. The increased pore-water pressure decreases shear strength, and earthflows or slumps are triggered. Flowage commonly ensues as a lobe or sheet that has a bulge at the lower end and cracks forming over the surface of the mass. An increase in tension upslope from the lower end of the hummocky surface might cause slippage at the approximate contact of impermeable clayey material with more permeable silty to sandy soil. Rotational slumping results at least in part of, but is generally confined to, the head area of the newly formed slide. Sharpe and Dosch (1942) made comparable observations in describing the mechanics of creep and earthflow on the basis of a series of borings near New Philadelphia, Ohio.

The delineation of the Claysville Limestone Member of the Greene Formation as mapped by Kent (1972) shows in many places a distinct relationship with the upper margins of landslides in the northern part of the area (fig. 9). Unmapped lower and higher limestone beds underlain by claystone elsewhere locally approximate the upper part of other slides (fig. 11). However, most earthflows take place along concave slopes characteristically mantled by varying thickness of colluvium; therefore, only inferences can be made regarding lithologic relationships in these areas.

\section{INTERPRETATION AND ANALYSIS OF EARTHFLOW ELEMENTS}

\section{ORIENTATION}

More than 75 percent of the recent slides took place on northwest- north- northeast- and east-facing slopes; the most conspicuous orientations are north and northeast (figs. 9, 10). Areas of old landsliding greater than $1 \mathrm{~km}$ in length are present on north-facing slopes above Short Creek, Hamestring Run, Lick Run, the east-west drainage west of the village of Prosperity, $\mathrm{Pa}$., and an unnamed drainage $1.5 \mathrm{~km}$ southwest of Prosperity.

An examination of the topography for these drainages reveals that the steepest slopes are those that face north. The slopes are covered mostly by forest growth, and, because they are steep, only parts of the slopes have been farmed as pasture or cropland. Less steep south-facing slopes have been extensively farmed and show fewer mass-movement features.

Several factors contribute to the high incidence of mass-movement features on north-facing slopes. Slopes facing north receive less exposure to the sun; after a rain, soils there remain wet longer than soils on southfacing slopes. East-facing slopes, of course, receive early-morning sunlight, but the drying effect on these soils is ineffective because of the low temperatures at that time of the day. Snow cover, obviously, lingers longest on slopes facing northwest to east. Conversely, higher rates of evaporation are found on south-facing slopes. The only consistently unstable south-facing slope areas are along laterally concave parts, typically at the heads of tributary drainages. Although recent slides on south-facing slopes are relatively uncommon, hummocky lower slopes (fig. 10) indicate periods of mass movement. Hummocky south-facing slopes are much more areally restricted than are north-facing slopes.

The combination of steeper slopes and greater soil moisture accounts for the higher incidence of mass movement on north-facing slopes. Presence or absence of trees is less important as a controlling influence on slope stability than are either slope steepness or soil moisture. Similar landslide and slope-exposure relationships are discussed by Van Buskirk (1977) for northeastern Ohio, Beaty (1956) for California, Harden (1976), and Colton and Holligan (1977), both for Colorado. Beaty (1956) observed that 70 percent of the earthflows east of Berkeley, Calif., took place on slopes facing north and east. Though Hadley (1961) did not discuss landsliding, he did mention comparable slope characteristics in the intermontane west.

MORPHOLOGY AND TOPOGRAPHIC FORM OF SLOPE ENVIRONMENT

In the Short Creek area, nearly 40 percent of the recent earthflows are approximately equidimensional. More than one-third are elongated perpendicular to the contour, and more than one-fourth are parallel to the contour. Most earthflows parallel to the topographic contour take place along planar to convex slopes, whereas most earthflows perpendicular to the contour lie within concave slopes or coves. Equidimensional forms are found in a variety of slope settings.

Both recent and old landslides have an affinity for concave slopes (longitudinally as well as laterally) (fig. 9, 10). Patton (1956) noted that recent earthflows were more common in coves or concave slopes than on other slope types. Both ground and surface water tend to concentrate along concave slopes. Unstable surface conditions are created where clayey soils that have at least a 


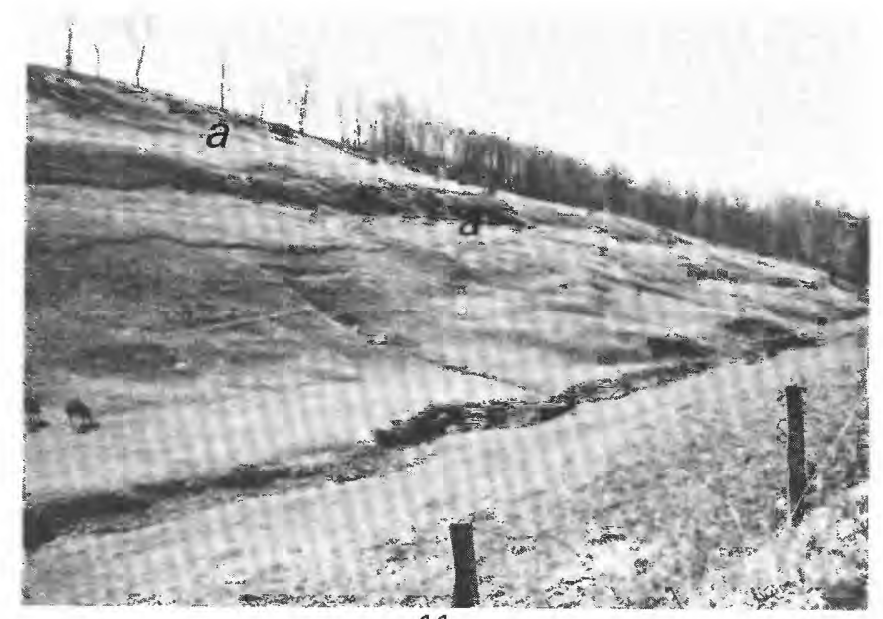

11

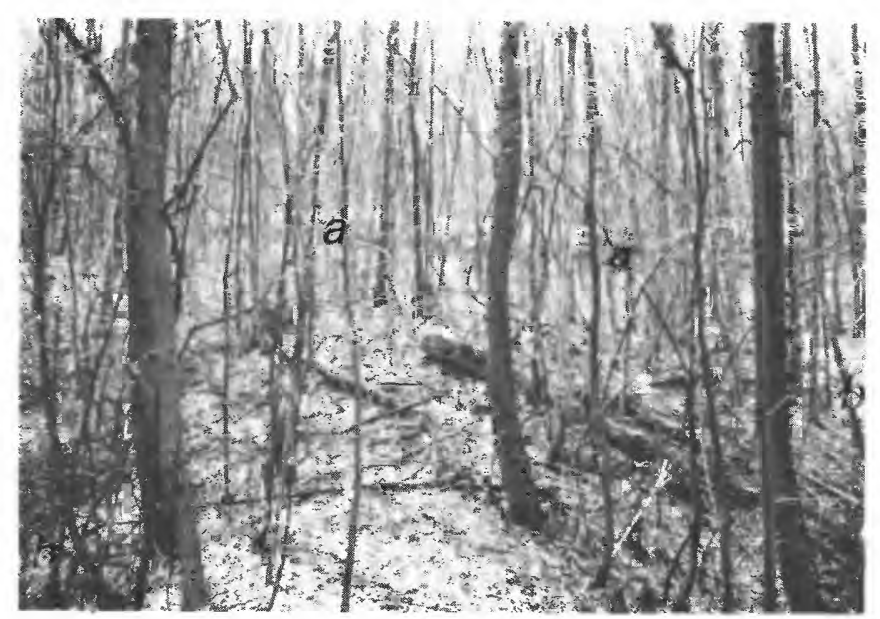

13
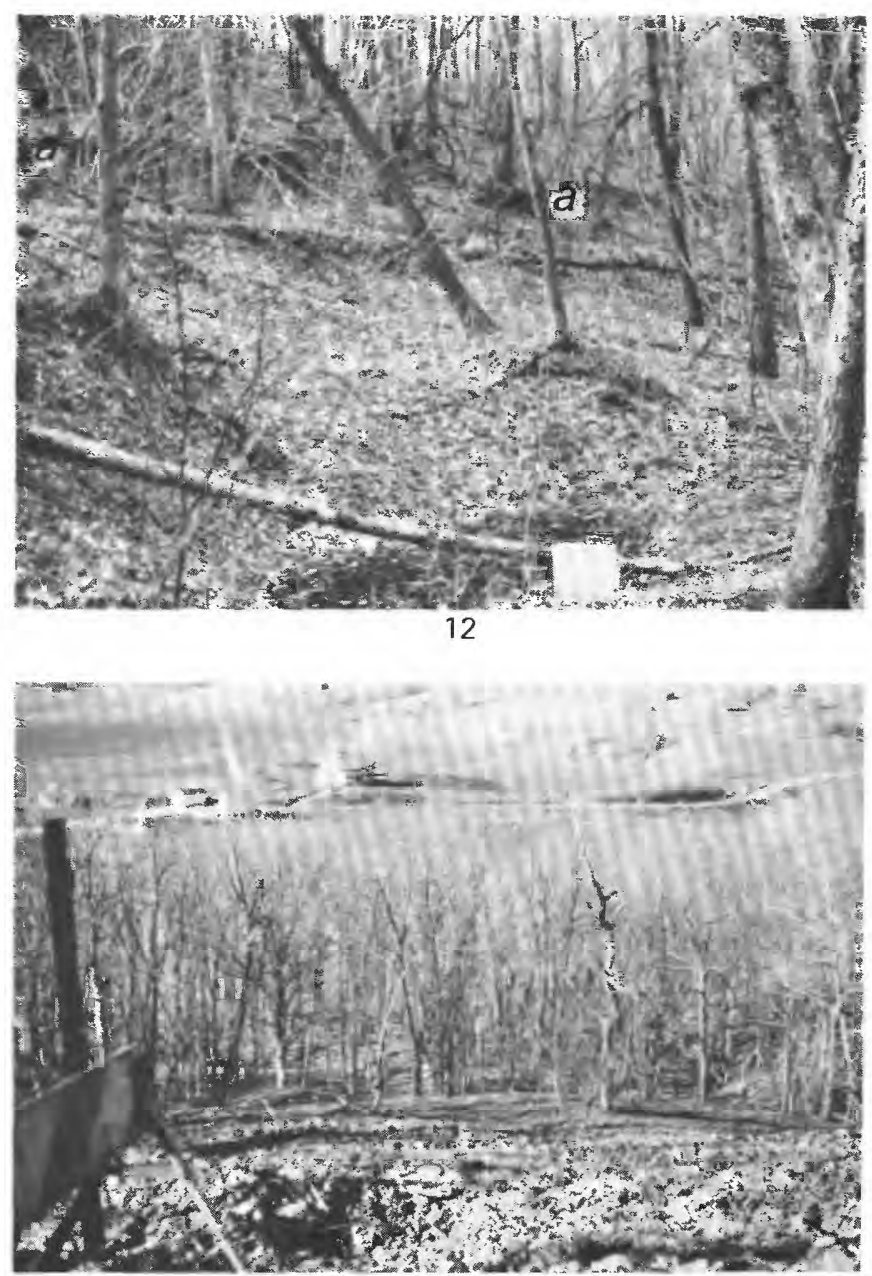

14

FiguREs 11-14:

11. - Recent earthflows along planar northeast-facing slope. Thin limestone beds are present at $a$.

12. - Head area of reactivated old slide. Note head scarp $(a)$ and evidence of slumping.

13. - View from old slide surface up toward frontal lobe of recent slide. Frontal lobe $(a)$ is approximately 1-1.5 m high. Relief of gullies $(b)$ increases lower on slope.

14. - View down recent slide showing older hummocky surface lower on slope.

moderate shrink-swell ratio are present. A lack of outcrops and a relatively thick accumulation of highly weathered material are characteristic of these "scoopedout" areas.

Kelsey (1978, p., 364) mentioned large earthflows in northern California that have bowl-shaped depressions in their upper parts. Amphitheater-shaped basins, formed by former episodes of mass movement, were noted by Nolan and others (1976) in the same region.

In the Short Creek area, more than 60 percent of the recent slides have formed along concave slopes. More than 25 percent and 12 percent occur on laterally planar and convex slopes, respectively. Slides can form on convex slopes that are better drained than adjacent slopes.
Such occurrences are due to the inherent instability of the soil, which, although thinner on noses of slopes, is still susceptible to sliding if minimal moisture conditions exist. Waltz (1971) discussed the significance of concave and convex slopes and their role in reflecting topographic control of surface runoff in two San Francisco Bay area counties. In West Virginia, Lessing and others $(1976$, p. 36) determined that 60 percent of their sampled slides took place along concave slopes.

\section{TRIGGERING MECHANISMS}

Man's influence in the distribution of present-day landslides in the Short Creek area is relatively minor when contrasted with mass movement in the Harmon Creek 
area or in urbanized Allegheny County (Briggs and others, 1975). In the Short Creek area, most of the mass movement has resulted from naturally unstable conditions. Prolonged periods of precipitation during late winter to early spring while the ground is thawing has been conducive to the formation of most earthflows. Short periods of intense rain that often take place during the warmer months of the year have had less effect on earthflow genesis. Oversteepening of slopes by stream erosion takes place at the point of maximum curvature of meander bends. Because the slopes have been undercut, slides often result. Overdip slopes ${ }^{1}$ (Briggs, 1974) do not control the siting of landslides in this area. If bedrock structure played a role, then landslides should be most pronounced along southeast-facing slopes on the basis of the structure contours (Kent, 1972).

A prime example of an area subjected to recent sliding due to precipitation alone is shown at locality 1 (fig. 9 ). An arcuate head scarp approximately $50 \mathrm{~m}$ in length is present along a forested concave slope. Tilted trees imply some rotational movement along an uneven surface marked by small ponds (fig. 12). The width of the slide is greater than its length. Below the prominent frontal lobe is a dissected, less steep forested area (15 percent grade) that represents the toe of an older more extensive earthflow (fig. 13). A small outcrop near the base of one of the older frontal lobes approximately $4 \mathrm{~m}$ in relief is almost completely masked by the colluvium of the earlier deposit.

Clearing of forested slopes for pasture is a factor in the reactivation of parts of steep north-facing slopes south of the village of Sparta, west of the village of Prosperity, and, locally, in the southeastern and southwestern parts of the area shown on the map.

At locality 2 (fig. 9), man's influence is apparent, as shown by the failure of roadfill in a concave-slope area. The area is part of an old landslide deposit, revealed by the hummocky and gullied forested surface seen in figure 14. Repeated attempts to stabilize the slope traversed by the paved road have failed. The author's observation indicated that surface water had not been diverted from this sensitive area.

\section{ASYMMETRICAL VALLEYS AND THEIR RELATION TO LANDSLIDING}

North-facing slopes that are steeper than opposing south-facing slopes are present in the Short Creek area (figs. 9, 10) and adjacent quadrangles in southern Washington County. These asymmetrical valleys are similar in form to valleys described in southern Indiana (Wayne, 1967; Culbertson, 1900; Newson, 1903), south-

${ }^{1}$ An overdip slope is defined as a land surface sloping in approximately the same direction as, but more steeply than, the dip of the strata. western Wisconsin (Judson and Andrews, 1955), western Wyoming (Walker, 1948), northwestern Alaska (Curry, 1964), eastern Wyoming (Hadley, 1961; Melton, 1960), southern California (Emery, 1947), New Jersey (Bascom, 1909), southern Ohio (Russell, 1924), and Virginia (Hack and Goodlett, 1960). Because of significantly greater insolation, the south-facing slopes are affected by more frequent freeze-thaw cycles. The slope gradient is reduced through weathering and sheet erosion. If the colluvial debris derived from the south-facing slopes and accumulated in an east-west channel cannot be effectively removed, the channel will shift its course toward the south side of its valley. Such a dynamic change leads to the undercutting of the north-facing slope (Wayne, 1967; Melton, 1960).

Erosion of the toe of the north-facing slope, commonly during flooding, results in its oversteepening and enhances the instability of the slope. During the early spring months colluvial parts of these slopes are extremely sensitive after a prolonged period of precipitation on an already saturated, probably snow-covered surface. The added weight of the soil combined with the increase in pore pressure and shearing stress is compounded by a decrease in frictional resistance and cohesion of the silty to clayey material. Sliding during or after a wet period commonly results.

The steepness and wetness of the north-facing slopes thus provide the optimum conditions for creep and earthflow activity. The same processes are markedly less conspicuous on the less steep and drier south-facing slopes where weathering and sheetwash are more characteristic. Hack and Goodlett (1960, p. 41) noted these features in their study of asymmetry in the Little River area of Virginia.

By contrast, the Harmon Creek valley (fig. 2) to the north shows no pronounced asymmetry. Wayne (1967, p. 401) reported that valleys occupied by large streams in southern Indiana show little or no asymmetry. The west-flowing Harmon Creek probably removed debris originating from south-facing slopes more effectively, and as a result channel shifting and undercutting of the north-facing slope were negligible. Then in the waning stages of Wisconsin glaciation, swollen waters of Harmon Creek steepened slopes wherever meanders occurred, regardless of the orientation of the slope. As a result, no pronounced asymmetry is apparent.

\section{SUMMARY}

Colluvium derived from fine-grained clastic rocks of the Conemaugh and Dunkard Groups is highly susceptible to landsliding in Washington Country.

In the Short Creek area of the southwestern part of the county, earthflows commonly take place in clayey to clayey silt soil and highly weathered rock derived from 
mudstone, claystone, limestone, and shale of the Dunkard Group. Asymmetrical valleys that have steep and moist north-facing colluvial slopes are conducive to mass movement.

To the north, red mudstone sequences in the Conemaugh Group correlative with similar strata in the Pittsburgh area underlie colluvial slump-earthflows in a wide zone roughly 30-80 $\mathrm{m}$ below the Pittsburgh coal bed. Strip-mining development has compounded the natural landslide environment in the Harmon Creek area. In many places, spoil-bank failures, slides along access roads, and mass movement of regraded rock waste have resulted.

\section{SOURCE AND IDENTIFYING DATA OF AERIAL PHOTOGRAPHS}

Figure 6. -U.S. Department of Agriculture, Agricultural Adjustment Administration. APT-92, 92-93.

Scale 1:20,000. Focal length of camera lens, $21 \mathrm{~cm}$. Date of photograph: June 5, 1939

Figure 7. A, B. - U.S. Geological Survey. GS-UG-4, 90-91. Scale 1:23,600. Focal length of camera lens, $15 \mathrm{~cm}$. Date of photograph: June 6, 1952.

Figure $8 A, B .-A$, U.S. Geological Survey. GS-VDWD-3,219-220; $B$, U.S. Geological Survey GS-VDWD-3, 266-267.

Scale 1:24,000. Focal length of camera lens, $15 \mathrm{~cm}$.

Date of photograph: December 7, 1975.

Figure 10. -U.S. Geological Survey GS-VDWD-3, 52-53. Scale 1:24,000. Focal length of camera lens, $15 \mathrm{~cm}$. Date of photograph: December 7, 1975.

\section{REFERENCES CITED}

Bascom, Florence, 1909, Description of the Trenton Quadrangle [New Jersey-Pennsylvania]: U.S. Geological Survey Geological Atlas, Folio 167, 24 p.

Beaty, C. B., 1956, Landslides and slope exposure [California]: Journal of Geology, v. 64, no. 1, p. 70-74.

- 1962, Asymmetry of stream patterns in the Bitteroot Range, Montana: Journal of Geology, v. 70, no. 3, p. 347-354.

Berryhill, H. L., Jr., Schweinfurth, S. P., and Kent, B. H., 1971, Coalbearing Upper Pennsylvanian and Lower Permian rocks, Washington area, Pennsylvania, pt. 1, Lithofacies, pt. 2, Economic and engineering geology: U.S. Geological Survey Professional Paper 621, $47 \mathrm{p}$.

Briggs, R. P., 1974, Map of overdip slopes that can affect landsliding in Allegheny County, Pennsylvania: U.S. Geological Survey Miscellaneous Field Studies Map MF-543, scale 1:125,000.

Briggs, R. P., Pomeroy, J. S., and Davies, W. E., 1975, Landsliding in Allegheny County, Pennsylvania: U.S. Geological Survey Circular $728,18 \mathrm{p}$.

Coates, D. R., 1977, Landslide perspectives, in D. R. Coates, ed., Reviews in engineering geology, v. 3, Landslides: Boulder, Colo., Geological Society of America, p. 3-28.
Colton, R. B., and Holligan, J. A., 1977, Photo interpretive map showing areas underlain by landslide deposits and areas susceptible to landsliding in the Louisville Quadrangle, Boulder and Jefferson Counties, Colorado: U.S. Geological Survey Miscellaneous Field Studies Map MF-871, scale 1:24,000.

Culbertson, Glen, 1900, The weathering and erosion of north and south slopes: Indiana Academy of Science Proceedings for 1899, p. $167-170$.

Currey, D. R., 1964, A preliminary study of valley asymmetry in the Ogotoruk Creek area, northwestern Alaska: Arctic, v. 17, no 2, p. 84-98.

D'Appolonia, E., Alperstein, R., and D'Appolonia, D. J., 1967, Behavior of a colluvial slope: American Society of Civil Engineers v. 93, paper 5326, Journal of Soil Mechanics and Foundations Division, no. SM4, p. 447-473.

Emery, K. O., 1947, Asymmetrical valleys of San Diego County, California: Southern California Academy of Sciences Bulletin, v. 46 , pt. 2, p. $61-71$.

Fisher, S. P., Fanaff, A. S., and Picking, L. W., 1968, Landslides of southeastern Ohio: Ohio Journal of Science, v. 68, no. 2, p. $65-80$.

Hack, J. T., and Goodlett, J. C., 1960, Geomorphology and forest ecology of a mountain region in the central Appalachians: U.S. Geological Survey Professional Paper 347, 66 p.

Hadley, R. F., 1961, Some effects of microclimate on slope morphology and drainage basin development: U.S. Geological Survey Professional Paper 424-B, p. 32-33.

Harden, C. P., 1976, Landslides near Aspen, Colorado: Colorado University Institute of Arctic and Alpine Research Occasional Paper 20,60 p.

Judson, S. Sheldon, Jr., and Andrews, G. W., 1955, Pattern and form of some valleys in the Driftless Area, Wisconsin: Journal of Geology, v. 63 , no. 4, p. 328-336.

Kelsey, H. M., 1978, Earthflows in Franciscan melange, Van Duzen River basin, California: Geology, v. 6, no. 6, p. 361-364.

Kent, B. H., 1972, Geologic map of the Prosperity quadrangle, southwestern Pennsylvania: U.S. Geological Survey Geologic Quadrangle Map GQ-1003, scale 1:24,000.

Kent, B. H., Schweinfurth, S. P., and Roen, J. B., 1969, Geology and land use in eastern Washington County, Pennsylvania: Pennsylvania Geological Survey, 4th series, Bulletin G56 (General Geology Report), $31 \mathrm{p}$.

Kimball, L. R., Consulting Engineers, 1974, Slope stability, v. 1, Report and field book [Research and demonstration of improved surface mining techniques in eastern Kentucky]: Washington, D.C., Appalachian Regional Commission Report ARC-71-66-T3, U.S. Department of Commerce National Technical Information Service PB-262-492, 80 p.

Lessing, Peter, Kulander, B. R., Wilson, B. D., Dean, S. L., and Woodring, S. M., 1976, West Virginia landslides and slide-prone areas: West Virginia Geological and Economic Survey, Environmental Geology Bulletin 15, 64 p.

Melton, M. A., 1960, Intravalley variation in slope angles related to microclimate and erosional environment: Geological Society of America Bulletin, v. 71, no 2, p. 133-144.

Newson, J. F., 1903, A geologic and topographic section across southern Indiana: Indiana Department of Geology and Natural Resources, 26th Annual Report, p. 227-302.

Nolan, K. M., Harden, D. R., and Colman, S. M., 1976, Erosional landform map of the Redwood Creek drainage basin, Humboldt County, California, 1947-74: U.S. Geological Survey Water Resources Investigation WRI 76-42, scale 1:62,500.

Patton, J. B., 1956, Earth slips in the Allegheny Plateau region: Journal of Soil and Waste Conservation, v. 11, p. 28-31. 
Philbrick, S. S., 1962, Old landslides in the Upper Ohio Valley [abs]: Geological Society of America Special Paper 68, p. 245-246.

Pomeroy, J. S., 1976a, Reconnaissance maps showing landslides in the Avella, Burgettstown, Claysville, Clinton, Midway, Prosperity, West Middletown, and Washington West quadrangles, western Washington County, Pennsylvania: U.S. Geological Survey OpenFile Report 76-789, scale 1:24,000, 8 sheets, with text.

1976b, Reconnaissance maps showing landslides in the Amity, Bridgeville, California, Canonsburg, Ellsworth, Hackett, Monongahela, and Washington East quadrangles, eastern Washington County, Pennsylvania: U.S. Geological Survey OpenFile Report 76-790, scale 1:24,000, 8 sheets, with text.

- 1977a, Geologic setting of landsliding in a 3-county area, western Pennsylvania: Geological Society of America Abstracts with Programs, v. 9, no. 3, p. 309-310.

__ 1977b, Preliminary reconnaissance map showing landslides in Beaver County, Pennsylvania: U.S. Geological Survey Open-File Report 77-245, 4 p., 1 pl, scale 1:50,000

1977c, Reconnaissance map showing landslides in Washington County, Pennsylvania: U.S. Geological Survey Open-File Report 77-307, scale 1:50,000; text 5 p., 2 pls.

1978, Isopleth map of landslides deposits, Washington County, Pennsylvania-A guide to comparative slope susceptibility: U.S. Geological Survey Miscellaneous Field Studies Map MF-1010, 2 sheets, scale 1:50,000.

Pomeroy, J. S., and Davies, W. E., 1975, Map of susceptibility to landsliding, Allegheny County, Pennsylvania: U.S. Geological Survey Miscellaneous Field Studies Map MF-685-B, 2 sheets, scale $1: 50,000$

Russell, R., 1924, Geomorphological evidence of a climatic boundary: Science, v. 74, no. 1924, p. 484-485.

Schweinfurth, S. P., 1976, Geologic map of the Avella quadrangle and part of the Steubenville East quadrangle, Washington County, Pennsylvania: U.S. Geological Survey Miscellaneous Investigation Series Map I-908, scale 1:24,000.

Sharpe, C. F. S., 1938, Landslides and related phenomena; a study of mass movements of soil and rock: New York, Columbia University Press, 136 p. (reprinted, 1960, Pageant Books, Paterson, N.J.)

Sharpe, C. F. S., and Dosch, E. F., 1942, Relation of soil creep to earthflow in the Appalachian Plateaus: Journal of Geomorphology, v. 5 , no. 4 , p. $312-324$.

U.S. Soil Conservation Service, 1973a, Volume 1, Soil interpretations for Beaver and Lawrence Counties, Pennsylvania: [Harrisburg, Pa.] Pennsylvania Department of Environmental Resources, 157 p.

- 1973b, Beaver County, Pennsylvania, interim soil survey report, v. 2, soil maps: [Harrisburg, Pa.] Pennsylvania Department of Environmental Resources, State Conservation Commission, 126 p.

- 1974a, Greene and Washington Counties, Pennsylvania, v. 1, soil interpretations: [Harrisburg, Pa.] Pennsylvania Department of Environmental Resources, State Conservation Commission, $103 \mathrm{p}$.

- 1974b Washington County, Pennsylvania, Interim soil survey report, v. 2, Soil maps: [Harrisburg, Pa.] Pennsylvania Department of Environmental Resources, $247 \mathrm{p}$.

Van Buskirk, D. R., 1977, The relationship between aspect and slope conditions in northeastern Ohio [abs.]: Geological Society of America Abstracts with Programs, v. 9, no. 3, p. 327

Varnes, D. J., 1978, Slope movement types and processes, chap. 2 in Schuster, R. L., and Krizek, R. J., eds., Landslides-analysis and control: National Academy of Sciences, Transportation Research Board Special Report 176, p. 11-33.

Walker, E. H., 1948, Differential erosion on slopes of northern and southern exposure in western Wyoming [abs.]: Geological Society of America Bulletin, v. 59, no. 12, pt. 2, p. 1360.

Waltz, J. P., 1971, An analysis of selected landslides in Alameda and Contra Costa Counties, California: Association of Engineering Geologists Bulletin, v. 8, no. 2, p. 153-163.

Wayne, W. J., 1967, Periglacial features and climatic gradient in Illinois, Indiana, and western Ohio, east-central United States, in Quaternary paleoecology-International Association of Quaternary Research, 7th Congress, 1965, Proceedings, v. 7: New Haven, Connecticut, Yale University Press, p. 393-414.

Wilson, Lee, 1968, Asymmetric valleys, in R. W. Fairbridge, ed., The encyclopedia of geomorphology, Encyclopedia of earth sciences series, v. 3: New York, Reinhold Book Corp., p. 30-34.

Zook, R. L., and Bednar, R. E., 1975, Landslide problems of the eastern Kentucky coal fields: Association of Engineering Geologists Bulletin, v. 12, no. 4, p. 251-260. 